\title{
The Relationship Between Spatial Configuration and Social Interaction in High-Rise Flats: A Case Study On The Jatinegara Barat in Jakarta.
}

\author{
Rifan Ridwana ${ }^{1, *}$, Budi Prayitno $^{2}$, and Adi Utomo Hatmoko ${ }^{2}$ \\ ${ }^{1}$ Student, Department Architecture and Planning, Faculty of Engineering Gadjah Mada University, Indonesia. \\ ${ }^{2}$ Lecturer, Department Architecture and Planning, Faculty of Engineering Gadjah Mada University, Indonesia.
}

\begin{abstract}
The construction of high-rise flats to minimize urban slum areas in Indonesia still create space use behavior problems for its residents due to the changes of space configuration between high-rise landed housing. Conventional high-rise flats cannot well accommodate the needs of social interactions happened in landed housing because of its spatial limitation that leads to uncertainty of space use behavior settings. This study aims to understand the relationship between spatial configuration on high-rise flats and social interaction levels of its residents. The object of study is Jatinegara Barat high-rise flats built to relocate slums community from the landed housing in Kampong Pulo. This study applies mix method research using space syntax method to analyze spatial configuration by looking at connectivity and space integration values, and then comparing it with social interaction data from place centered observation to find out the level of interaction and spaces tendency used interaction place.

The results of this study indicate that: (1) the relationship of spatial configuration to social interaction level in Jatinegara Barat flats can be positive or negative. (2) Positive relationships are found on the1st and 2ndfloor areas. High configuration values with high interaction levels are found in shared spaces on the 1st and 2nd floors with characteristics such as open space, large space, and availability of interaction supporting elements, while low configuration values with low interaction levels are found in more confined spaces such as private spaces and narrow corridors. (3) Negative relationships are found in the corridor and shared space in front of the elevator on each typical floors. Shared space in front of the elevator that has high spatial configuration value with large area show a low level of social interaction. While corridor with lower configuration value with the narrow area but have supporting elements such as chairs, mats, and shops have a higher level of social interaction. (4) This study shows that in the case of the relationship between spatial configuration and social interaction, availability of interaction supporting elements has greater influence rather than any other spatial factors.
\end{abstract}

\section{Introduction}

The issue of slum settlement which is not a new problem in Indonesia until now has not been completely resolved. In order to eradicate slums in Indonesia, since the 1970s the government has introduced a village improvement program to improve informal settlements. Flats become one of the programs being intensified by the government at this time. But the construction of flats raises other problems. Social problems often appear in the flats related to the issue of cultural behavior of residents. They face obstacles in interacting with each other, especially because of the limitations of the space available to the flats. In an effort to support the development of a more suitable and appropriate vertical shelter to the character of eastern society, especially Indonesia, a study of the relationship between spatial configuration and interaction levels in the towers is required. This study will examine the relationship between the configuration of flat spaces to the social interactions of its inhabitants based on space syntax theory in the Jatinegara Barat, East Jakarta.

\section{Research Questions}

1. How is the relationship between spatial configuration and social interaction in Jatinegara Barat flat?

2. What are the factors that play a major role in the relationship between spatial configuration and social interaction in Jatinegara Barat flat?

\section{Research Purposes}

1. Understanding the relationship between spatial configuration and interaction level of residents of Jatinegara Barat flat.

2. Understanding Factors that play a major role in 
the relationship of spatial configuration to the interaction of residents Jatinegara Barat flat.

\section{Literature Review}

\section{Flats}

According to regulation no. 16 year 1985 about flats, flats are high rise buildings built in an environment, divided into structured parts functionally in horizontal and vertical directions that each units can be owned and used separately, especially for shelter, equipped with shared parts, shared objects and shared ground.

\section{Social Interaction}

Social interaction is a mutual relationship between people in a group or community / society. The power of existence in a social interaction is very meaningful in relation to the formation of the physical environment space. (jan Gehl, 1996). some aspects that play a role in the process of social interaction:

1. Personal space : Hall (1966) argued that the personal space is a distance to communicate, where the distance between individuals is a distance communicate. This distance can also be called proxemic distance or proximity distance.

2. Territory : Territory is a tendency in control of an area. (Altman, 1984)

3. Space Elements : (Rapoport, A. 1982) The interaction between the behavior and the environment as a nonverbal communication has the meaning of being divided into three elements: Fixed-feature element, Semifixed-element feature, Nonfixed-feature element.

\section{Space Syntax}

Configuration can be interpreted as a set of relationships where there are interdependent objects in one structure (Hillier: 2007). The technique of configuration analysis is called space syntax (Darjosanjoto, 2005, extracted from Hillier and Hanson, 1984; and Hillier, 1996). by analyzing the spatial pattern, can be known how the relationship relation in an object either micro scale up to macro. (Hanson, 1998; Dawson, 2002). There are 3 variables in space syntax analysis:

1. Connectivity. Connectivity is a dimension that measures the local property by counting the amount of space directly connected to each of the adjacent spaces in a spatial configuration (Hillier et al :1993 dan Hillier et al: 1987).

2. Integrity. Integrity is a dimension that measures the global property of the relative positions of each space over the other spaces in a spatial configuration (Hillier et al: 1987 dan Hillier et al: 1993).

3. Intelligibility. Intelligibility is the highest stage of measurement in space syntax. The value of intelligibility indicates the level of correlation between the measurement of local scale (connectivity) with the measurement of global scale (integrity)..

\section{Research Methods}

This research use a method of combining quantitative with qualitative methods called Mixed Methods Research. This research uses Sequential explanatory approach. This method is characterized by data collection and quantitative data analysis in the first stage, and followed by the collection and analysis of qualitative data in the second stage. space syntax simulation is used for quantitatif method using Depthmap software, where place centered mapping observation and interview are use for qualitative method.

\section{Research Object}

The location of this research is Jatinegara Barat flats in West Jakarta. This flat consists of 2 16-storey towers with 14 floors of residential and 2 public floors. The Jatinegara Barat Flat consists of 2 towers with 2 floors which basically functioned as a public area for two towers. Most of the people's livelihoods work in the informal sector as a seller of grocery, shop, open sidewalks, porters, SPG markets, laundry workers.

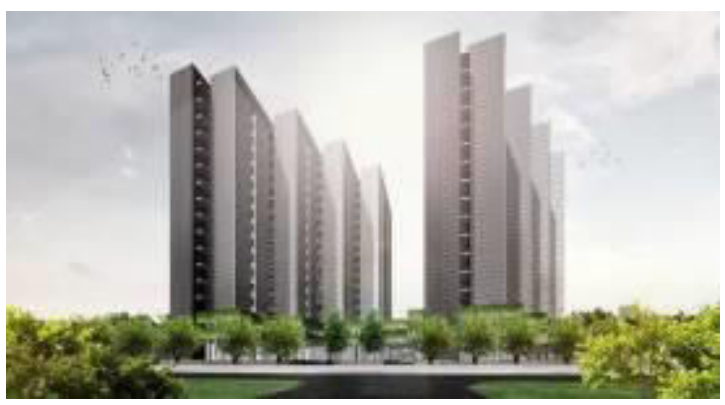

Fig. 1. Jatinegara Barat Flat. Source: UPT Jatinegara Barat's Document.

This research is focused on studying the space used for interaction activities. this interaction space is an informal space that accommodate any interaction activities. unit observation to be studied are all spaces used by the residents of Jatinegara Barat flat for interaction activities on residential units, hallways corridors, public spaces along with the type of interaction activities that occur. 


\section{Variables}

Table 1. Space Configuration Variables.

\begin{tabular}{|l|l|l|l|l|}
\hline \multicolumn{1}{|c|}{ Variable } & \multicolumn{1}{|c|}{ Data } & \multicolumn{1}{|c|}{ Parameter } \\
\hline 1 & $\begin{array}{l}\text { Space Integration } \\
\text { (value of space } \\
\text { relation with all } \\
\text { other room in } 1 \\
\text { floor) }\end{array}$ & $\begin{array}{l}\text { - Amount of space } \\
\text { - Space Configuration } \\
\text { - Space layout } \\
\text { - the location of the room } \\
\text { furniture }\end{array}$ & $\begin{array}{l}\text { Using Convex map } \\
\text { Analysis. } \\
\text { Depth. Range of color } \\
\text { spectrum from blue to } \\
\text { red. } \\
\text { Blue: low integration } \\
\text { level } \\
\text { Red: high integration } \\
\text { level }\end{array}$ & $\begin{array}{l}\text { The higher the value of } \\
\text { integration of a space, the } \\
\text { greater the tendency for social } \\
\text { interaction }\end{array}$ \\
\hline 2 & $\begin{array}{l}\text { Space connectivity } \\
\text { (the amount of } \\
\text { connected space } \\
\text { with the space } \\
\text { around it) }\end{array}$ & $\begin{array}{l}\text { - The location of the } \\
\text { Door } \\
\text { - Circulation layout } \\
\text { - The amount of } \\
\text { circulation } \\
\text { - Visibility of space }\end{array}$ & $\begin{array}{l}\text { spectrum from blue to } \\
\text { red. } \\
\text { Blue: } \text { low level of } \\
\text { connectedness. } \text { low depth } \\
\text { value } \\
\text { Red: high connectedness, } \\
\text { high depth value }\end{array}$ & $\begin{array}{l}\text { The higher the value of depth, } \\
\text { the higher the value of space } \\
\text { connections so as to be directly } \\
\text { proportional to the tendency of } \\
\text { meeting and the movement of } \\
\text { people. }\end{array}$ \\
\hline
\end{tabular}

Table 2. Social Interaction Variables.

\begin{tabular}{|c|c|c|c|c|}
\hline & variable & Data & Parameter & relationship \\
\hline 1 & Personal space & $\begin{array}{l}\text { - the amount of space } \\
\text { - Number of people in } \\
\text { one room } \\
\text { - Distance between } \\
\text { people }\end{array}$ & $\begin{array}{l}\text { Distance between people. } \\
\text { Standard Social distance } \\
\text { (2.1-3.6 meters) }\end{array}$ & $\begin{array}{l}\text { Comfort in interaction is } \\
\text { influenced by personal space, } \\
\text { personal space optimal in } \\
\text { conducting social relations is } \\
\text { about } 2.1-3.6 \text { meters. }\end{array}$ \\
\hline 2 & territory & $\begin{array}{l}\text { - Space boundaries } \\
\text { - Ownership of space } \\
\text { (private-public) } \\
\text { - Space elements }\end{array}$ & $\begin{array}{l}\text { Level of ownership: } \\
\text { - Public } \\
\text { - Semi-public } \\
\text { - Semi-private } \\
\text { - - private }\end{array}$ & $\begin{array}{l}\text { The more public the nature of } \\
\text { the territory of a space, the } \\
\text { higher the tendency of social } \\
\text { relations in the space. }\end{array}$ \\
\hline 3 & Space elements & $\begin{array}{l}\text { - the amount of space } \\
\text { - space openings } \\
\text { - circulation layout } \\
\text { - furniture elements }\end{array}$ & Availability of furniture & $\begin{array}{l}\text { The more facilities provided } \\
\text { make it more comfortable for } \\
\text { people to stay and increase the } \\
\text { likelihood of social activities }\end{array}$ \\
\hline
\end{tabular}

\section{Research Stages}

The research phase of this mixed method research starts from (1) the quantitative research phase using space syntax simulation to find out how the configuration and connectivity of the flat and identify the spaces tendency used for social interaction. followed by (2) qualitative research stage using place centered mapping observation and direct interview. this second phase is used as a verification step of the simulation result. whether it is appropriate or different from the actual data that occurred in the field. (3) data comparation from phase 1 and stage 2 .

\section{Result and Discussion}

\section{Result and Discussion Correlation Between Space Connecitivity and Social Interaction Level}

\section{Ground Floor}

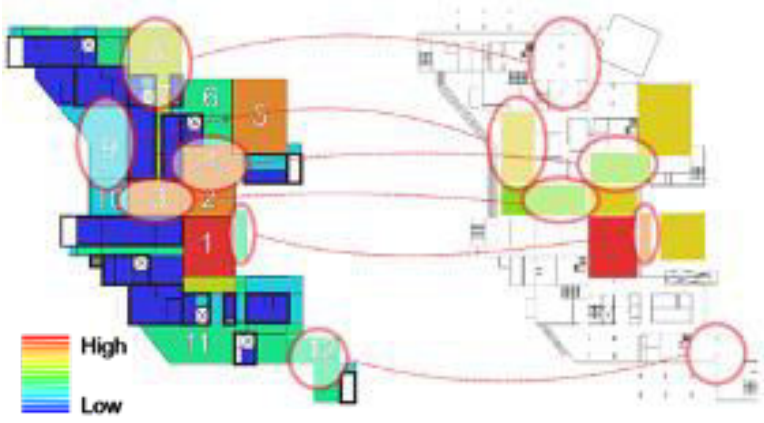

Fig. 2. Comparison of Connectivity Simulation Data with Field Observation Data at Ground Floor. 


\section{Positive Correlation}

Judging from the comparation of simulation data and field observation, spaces that have high connectivity and also have high interaction levels are room 1 (hall), 2 (hall), and 5 (shared open space). Meanwhile, spaces with low connectivity as well as low interaction levels include closed spaces such as classrooms, offices, utility rooms, and other private spaces, as well as some open spaces such as rooms 6 , 11 and 12.

\section{Negative Correlation}

Spaces on the 1st floor that have high connectivity but have low interaction levels are 3,4 , and 8 , while spaces that have low connectivity but have high interaction levels are open space 9 , and 10 .

\section{Second Floor}

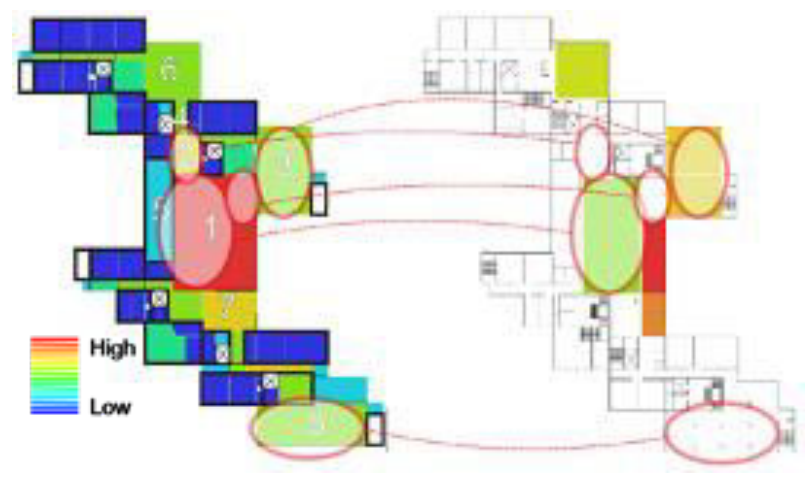

Fig. 3. Comparison of Connectivity Simulation Data with Field Observation Data at Second Floor.

\section{Negative Correlation}

\section{Positive Correlation}

Space that has connectivity and also has a level of interaction is almost the same is in space 3, 7, and some areas in space 1. This space is open space that is provided as a place of economy residents Jatinegara Barat tower. Meanwhile, spaces with low connectivity and low interaction rates include closed spaces such as closed kiosks and other private spaces, as well as some open spaces such as spaces 2, 6, 8.

\section{Negative Correlation}

Spaces that have high connectivity but have low interaction levels are 1,2, and south corridors. While spaces that have low connectivity but have a high level of interaction is space 3.

\section{Typical Floor}

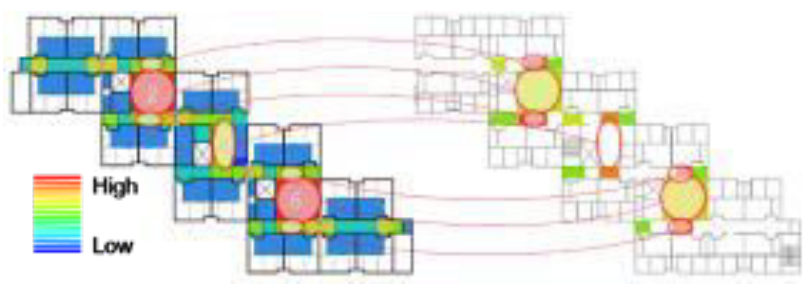

Fig. 4. Comparison of Connectivity Simulation Data with Field Observation Data at Typical Floor.

\section{Positive Correlation}

Spaces that have connectivity and also have a comparable level of interaction include corridor spaces in residential areas in general with low connectivity and interaction rates.

\section{Negative Correlation}

Spaces with high connectivity but low interaction rates are 2 , 4 and 6 spaces (elevator front room), whereas lowconnectivity spaces with high interaction levels are spaces on the north and south sides of the front room of the elevator.

\section{Correlation Between Space Integration and Social Interaction Level}

\section{Ground Floor}

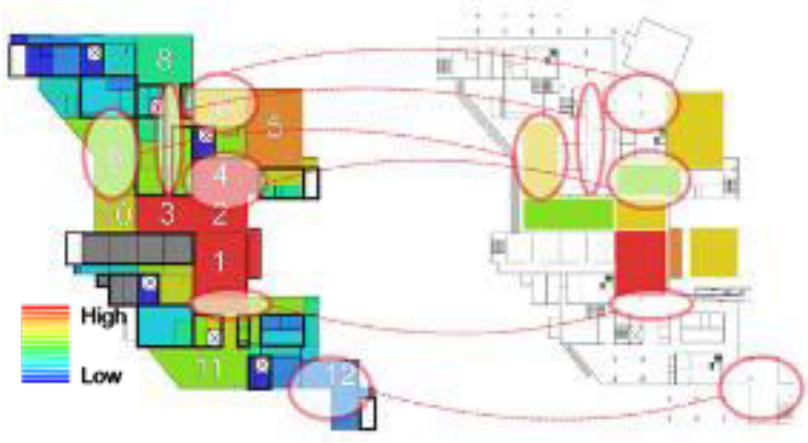

Fig. 5. Comparison of Integration Simulation Data with Field Observation Data at Ground Floor. 


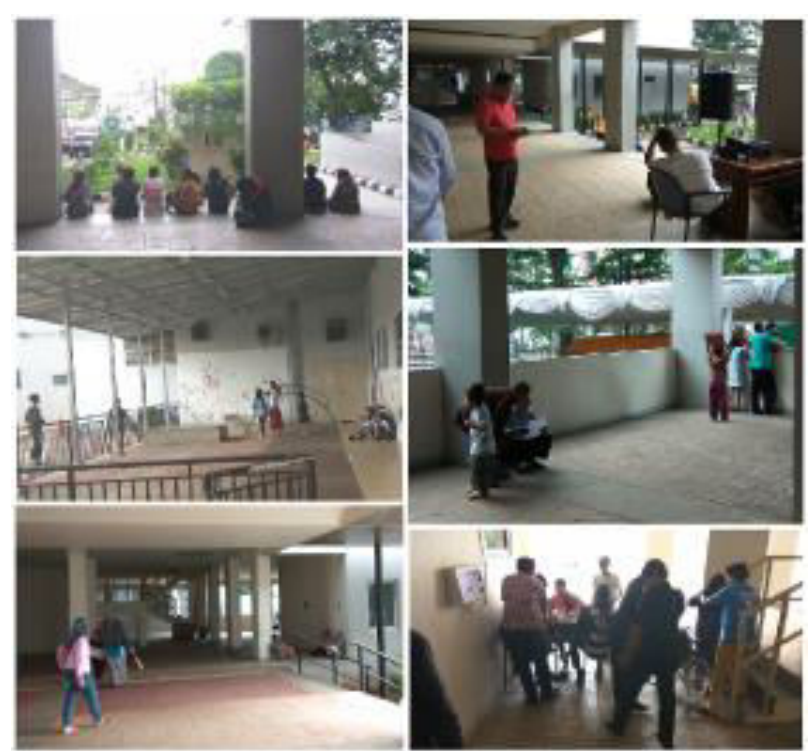

Fig. 6. Social Activities at Ground Floor.

\section{Positive Correlation}

Judging from the comparation of simulation data and field observation, spaces that have high integration and also have high interaction level are room 1 (hall), 2 (hall), 5 (joint open space), and 9 (park paud). These spaces are a common open space that is provided as a gathering place residents Jatinegara Baratern. Meanwhile, low-connectivity spaces as well as low interaction rates include closed spaces such as classrooms, offices, utility rooms, and other private spaces, as well as some open spaces such as spaces 8,11 and 12 .

\section{Negative Correlation}

Judging from the comparison of simulation data and field observation, the chambers that have high integration but have low interaction level are the northern corridor room, space 3 , 4 , and 6.

\section{Second Floor}

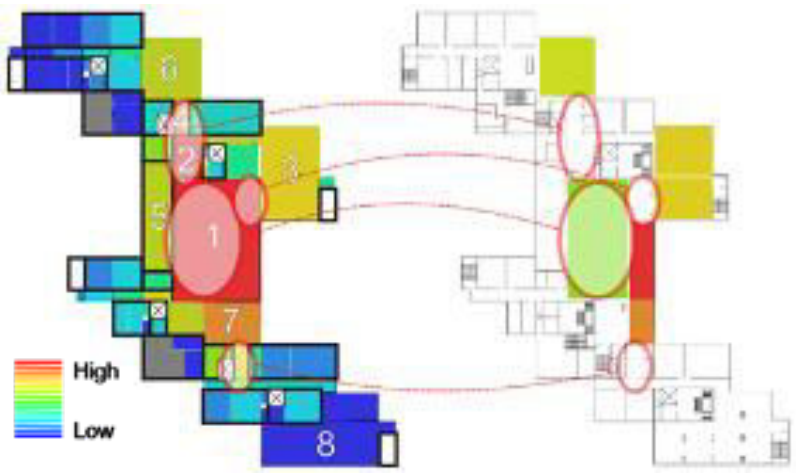

Fig. 7. Comparison of Integration Simulation Data with Field Observation Data at Second Floor.

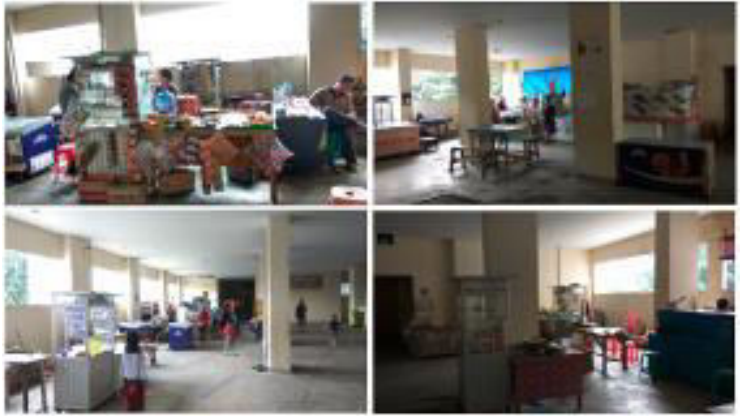

Fig. 8. Social Activities at Second Floor.

\section{Positive Correlation}

Spaces that have integration and also have a level of interaction that is almost the same on the second floor is in space 3, 7, and some areas in space 1 . These spaces are open space shared as a place of economic transactions residents Jatinegara Barat . Meanwhile, low-connectivity spaces as well as low interaction rates include closed spaces such as closed kiosks and private spaces such as offices and utilities, as well as some open spaces located in the north and south of such buildings open space number 6 and 8 .

\section{Negative Correlation}

Spaces that have high connectivity but have low interaction levels are open space 1, 2, and south corridor. While spaces with low connectivity but high interaction rates are open space alongside number 3 on the north west side of the building.

\section{Typical Floor}

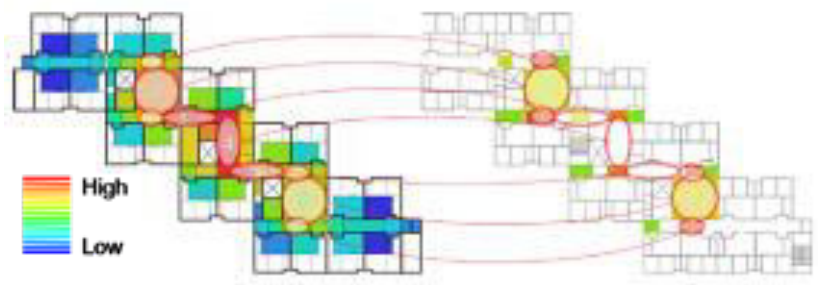

Fig. 9. Comparison of Integration Simulation Data with Field Observation Data at Typical Floor.
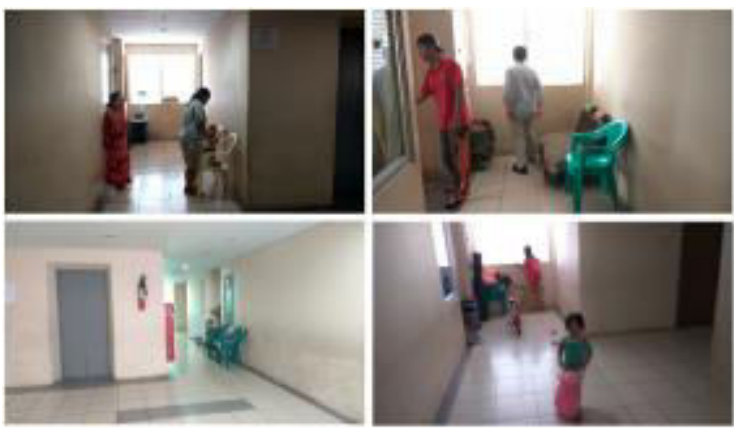

Fig. 10. Social Activities at Typical Floor. 


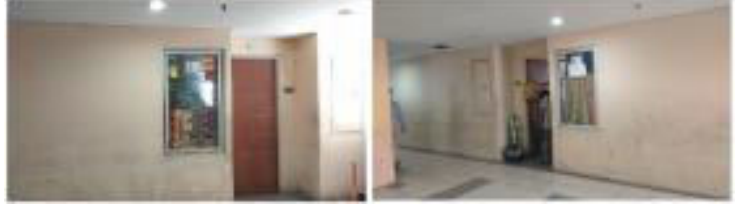

Fig. 11. Comparison of Integration Simulation Data with Field Observation Data at Ground Floor.

\section{Positive Correlation}

Judging from the comparison of simulated data and field observations, spaces that have integration and also have a comparable level of interaction on a typical floor tower include corridor spaces in residential areas in general with low connectivity and interaction values, and some areas on the north side of south room 4 .

\section{Negative Correlation}

Spaces that have high connectivity but have low interaction levels are 2, 4 and 6 spaces (elevator front room), while spaces that have low connectivity but have a high level of interaction is the space on the north and south side of the front room elevator.

\section{Literature Review}

\section{Conclusion}

1. Configuration of space (integration and space connectivity) affect the level of interaction residents in Jatinegara Barat flat. The correlation of spatial configuration to the level of interaction can be positive or negative.

2. Positive correlations with high interaction rates are found in several common spaces on the first and second floors with open space characteristics, broad, and high integration and connectivity values. While a positive correlation with low interaction rates was found in spaces with narrow private territories enclosed with low integration and connectivity values.

3. Negative correlations found in spaces that have interaction support elements such as the presence of chairs, mats, stalls, although the configuration value of space is small. These conditions are found in typical corridor areas on the floor, as well as some common open spaces. While positive correlations are found in some common room on the first floor, the middle area of the hall hall of the second floor, as well as the front area of the elevator on a typical floor that does not have the interaction supporting elements as found in other spaces in the towers with high interaction levels.

4. The main factors that play a role in the relationship of space configuration to the level of interaction of citizens in the rusun Jatinegara Barat is the existence of spatial elements supporting interactions such as furniture and chair mats stalls selling citizens, compared with the size dimensions of space.

5. Other factors that have an influence on the level of interaction among residents of west jatinegara towers include: dimensions and characteristics of space, territorial space, and the regulation factor towers Jatinegara Barat.

\section{Suggestion}

1. the provision of interaction supporting elements is needed in spaces that have high potential for social interaction so that space can function optimally to accommodate interaction activities.

2. In addition to the space configuration settings, the design of flats should be balanced with consideration of physical, psychological and social environmental factors into the design.

3. to develope a better and more innovative high-rise housing in the future, it is necessary for architects, developers, communities, and governments to play a role in the realization of flats that adopt the social life of this urban village in the midst of society.

\section{References}

Alexander. C, dkk. (1977). A Pattern Language. NY : Oxford university Press.

Alitajer, dkk. (2016). Privacy At Home: Analysis Of Behavioral Patterns In The Spatial Configuration Of Traditional And Modern Houses In The City Of Hamedan Based On The Notion Of Space Syntax. Frontiers Of Architectural Research.

Altman, dkk. (1984). Environmental Psychology. London: Holt, Rinehart and Wiston, Inc.

Ananto, S.D. (2015). Adaptasi Teritorialitas Pada Permukiman Horisontal Ke Dalam Permukiman Vertikal. Prosiding Temu Ilimiah IPLBI 2015.

Andrade, Pamela, dkk. (2011). Experiment In Public Housing Vol. 1 - A Reexamination Of Subsidized Housing Policy \& Design. Massachusetts: Northeastern University.

Aziz, A.A, dkk. (2012). Relationships Of Spatial Properties In Low-Cost Flats Configurations And Residents Local Social Contact. ASIA Pacific International Conference On Environment-Behaviour Studies.

Barada, W.P \& Mutlari, Dhani. (2013). Analisis Space Syntax Rumah Susun Berbasis Gang Kampung. Simposium Nasional RAPI XII FT UMS Semarang.

Hillier, B. And J. Hanson. (1984). The Social Logic Of Space. Cambridge: Cambridge University Press.

Hillier, Bill. (2007). Space Is The Machine. London: University College London.

Peponis J, Wineman J. (2001). Spatial Structure Of Environment And Behavior, Handbook Of Environmental Psychology. Canada.

Prayitno, Budi. (2013). An Analysis Of Consolidation Patterns Of Kampung Alley Living Space In Yogyakarta, Indonesia. Journal Of Habitat Engineering And Design 2013, 5(1). 
Siregar, Johannes P. (2014). Metodologi Dasar Space Syntax Dalam Analisis Konfigurasi Ruang. Malang: Universitas Brawijaya.

Sofian, D. Ananto. (2015). Adaptasi Teritorialitas pada Permukiman Horisontal ke dalam Permukiman Vertikal. Bandung: Institut Teknologi Bandung.

Turner, Alasdair. (2001). Depthmap: A Program To Perform Visibility Graph Analysis. Atlanta: Proceedings 3rd International Space Syntax Symposium. 